\title{
Development and Characterization of Ultra Low Cement Castable Cordierites by Thixotropic Properties Mixtures
}

\author{
Ana M. Paniagua-Mercado ${ }^{1}$, Arturo Méndez-Sánchez ${ }^{1}$, Elvia Díaz Valdés ${ }^{1}$, \\ Concepción Mejía García ${ }^{1}$, Paulino Estrada Díaz ${ }^{2}$ \\ ${ }^{1}$ Depto. de Física, Escuela Superior de Física y Matemáticas, Instituto Politécnico Nacional, Col. Lindavista, México \\ ${ }^{2}$ Sector-Ceramics and Refractories, Manuchar International, México \\ Email: ampani@esfm.ipn.mx, pestrada@manuchar.com.mx
}

Received 2012

\begin{abstract}
The main target in this investigation was to take advantage of the reology properties of the tixotropic mixes in Ultra Low Cement Castables (ULCC). The cordierite phase in refractory mix can be obtained using raw materials with magnesium oxide in its composition, such as, $\mathrm{Mg}(\mathrm{OH})_{2}$ or $\mathrm{H}_{2} \mathrm{Mg}_{3}\left(\mathrm{SiO}_{3}\right)_{4}$ (Talc mineral), with a content of $63.5 \% \mathrm{SiO}_{2}, 31.7 \% \mathrm{MgO}$ and $4.8 \% \mathrm{H}_{2} \mathrm{O}$. In this investigation, as magnesium source, a commercial calcined magnesite with $90 \% \mathrm{MgO}$ was used. This mineral was selected instead of Talc mineral, because this last contains more impurities in its composition that tend to form more amounts of liquid phases with low fusion points. For this work two different ULCC mixes were designed. These were fired at $1260^{\circ} \mathrm{C}$, the cordierite phase was quantified in each mix.
\end{abstract}

Keywords: Reology; Thixotropic Mixtures; Ultra Low Cement Castables; Cordierite

\section{Introduction}

There are in the market, several industrial methods and a wide of conventional raw materials to produce cordierite mixes $\left(\mathrm{MgO} \cdot \mathrm{Al}_{2} \mathrm{O}_{3} \cdot \mathrm{SiO}_{2}\right)$. The complete phase transformation is around $1300^{\circ} \mathrm{C}$ depending on the raw material used in the mix [1]. The industrial application is mainly focus where high thermal shock resistant, low thermal expansion and corrosion resistance are demanded. Such is the case of the cordierite refractory plates used for the conventional firing of sanitary and tableware, or recently used as substrate material in microelectronics [2]. The main manufacturing processes to develop cordierite phase are the sol-Gel method [3], co-precipitation [4], solid-state reaction [5] and by slurry. Aluminosilicate based ultra low cement castables (ULCC) are widely used mainly in the Steel and cement industries due to improved refractory properties at high temperatures. The bonding system in ultra low cement castables is achieved by using high alumina calcium aluminate cement.

Increasing the cement content in the concrete mix also increases the amount of liquid phases as the anorthita $\left(\mathrm{CaAl}_{2} \mathrm{Si}_{2}\right.$ $\left.\mathrm{O}_{8}\right)$ and gelenite $\left(\mathrm{Ca}_{2} \mathrm{Al}_{2} \mathrm{SiO}_{7}\right)$. These both tend to reduce the amount of free silica and decrease, in an important way, its chemical corrosion resistance. This last affects negatively their mechanical properties at high temperatures and in consequence the thermal shock resistant comes down. The lime/silica ratio is very important in the formation of liquid phases and its viscosity at high temperatures, because it affects the strength and corrosion resistance [6]. The use of very low amounts of high alumina cement in ULCC is principally to avoid the liquid phases formation inside the refractory matrix. Other important variable is the particle size distribution because it has a major impact in

*Work supported by Instituto Politécnico Nacional through project SIP-IPN 20120167. the reology of ULCC and in the final physical properties [7].

\section{Experimental Procedure}

Table 1 shows the chemical formulation of the two concrete mixes tested in this investigation. For each one of the designed mixes the preparation was as follows. First, the raw materials were dry mixed for at least 1 minute, after that, the deflocculant (sodium tripolifosfate); the polypropylene fibers and the high alumina cement were added to the final mix. At once, the water was added slowly and mixed 10 second more. After the mix was placed in a vibratory table (3000 cps), for no more than 30 seconds up to the mix, it got a thixotropic behavior.

After the vibratory step, the mix was allowed to dry and it was set for 12 hours at room temperature $\left(25^{\circ} \mathrm{C}\right)$. Afterwards the mix was dried $24 \mathrm{~h}$ in a laboratory stove at $110^{\circ} \mathrm{C}$. Finally, the mix was calcined between $1260^{\circ} \mathrm{C}-1280^{\circ} \mathrm{C}$ during $5 \mathrm{~h}$, in a gas furnace. In order to determine the cordierite forming and main phases present, the calcined samples were analyzed by $\mathrm{X}$-ray diffraction in a Siemens D-500 diffractometer, with $\mathrm{K} \alpha$ of $\mathrm{Cu}$ in the Bragg-Brentano configuration, in a 2 range of $10^{\circ}$ $120^{\circ}$. Micrographs of each one of the two calcined mixes were obtained with secondary electrons, at $800 \mathrm{X}$ of magnification, in a scanning electron microscopy JEOL-6300.

Table 1. Chemical Formulation of Mixtures.

\begin{tabular}{ccc}
\hline Compound & MIX I (\%) & MIX II (\%) \\
\hline $\mathrm{Al}_{2} \mathrm{O}_{3}$ & 47.92 & 47.49 \\
$\mathrm{SiO}_{2}$ & 20.86 & 41.02 \\
$\mathrm{CaO}$ & 0.80 & 1.08 \\
$\mathrm{MgO}$ & 27.15 & 7.37 \\
$\mathrm{Fe}_{2} \mathrm{O}_{3}$ & 1.08 & 0.82 \\
$\mathrm{TiO}_{\mathrm{K}} \mathrm{O}$ & 1.22 & 1.19 \\
$\mathrm{Na}_{2} \mathrm{O}$ & 0.65 & 0.66 \\
$\mathrm{Na}_{2}$ & 0.29 & 0.31 \\
\hline
\end{tabular}




\section{Results and Discussion}

\subsection{Chemical Analysis}

Specific raw materials were selected to design the ULCC cordierites. Oxide or other non-clay powders generally have poor workability when they are mixed with water and settling rapidly at lower water levels. For this reason, it was utilized some deflocculating chemicals to get a thixotropic behavior. In ULCC mix the amount of water is a problem because higher amount of water, than that required, is to the detriment of the final physical properties of the refractory concrete as \%Porosity and density (see Table 2).

\subsection{Physical Properties}

The physical properties of the mixtures were calculated and they are shown in Table 3.

The physical properties reported for the mix I, with a greater amount of fine particles than for mix II, table III, the fines are because the raw materials used for mix I are more than for mix II, show that it was required more water in its preparation than for mix II.

It can be also observed from mix I, that at higher water content in the mixII, the density decreases and the porosity too, Table 3.

Increases water resulting in a negative effect for the final physical properties. For Mix II, with a greater amount of coarse particles, until the raw mix, the demand of water was lower than for mix I, and this was reflected in its final physical properties.

\subsection{X-ray Diffraction}

In the patterns of X-ray diffraction shown in Figure 1, the different phases contained in the mixes I and II are presented. These were quantified with the peaks getting by X-ray diffraction of mixes burned.

Table 2. Physical properties of the mixtures.

\begin{tabular}{|c|c|c|c|c|c|}
\hline $\begin{array}{c}\text { Mix/ } \\
\text { Property }\end{array}$ & $\begin{array}{c}\text { Setting } \\
\text { Time (min) }\end{array}$ & $\begin{array}{c}\text { Water } \\
\text { Mixed }(\mathrm{mL})\end{array}$ & $\begin{array}{l}\text { Density } \\
\left(\mathrm{g} / \mathrm{cm}^{3}\right)\end{array}$ & $\begin{array}{c}\text { Absorption } \\
(\%)\end{array}$ & $\begin{array}{c}\text { Porous } \\
\text { (\%) }\end{array}$ \\
\hline MIX I & 160 & 12.5 & 1.95 & 13.8 & 27.0 \\
\hline$M I X$ & 80 & 8.5 & 2.07 & 9.6 & 20.0 \\
\hline
\end{tabular}

Table 3. Granulometry and density of raw materials.

\begin{tabular}{lcc}
\hline \multicolumn{1}{c}{ Raw materials } & $\begin{array}{c}\text { Particle Size } \\
(\boldsymbol{\mu m})\end{array}$ & $\begin{array}{c}\text { Density } \\
(\mathbf{g} / \mathbf{m l})\end{array}$ \\
\hline Magnesium Oxide & 590 & 3.10 \\
Calcined Kaolin & $74-2380$ & 2.52 \\
Microsilica & 44 & 2.70 \\
High Alumina Cement & 53 & 0.90 \\
Calcined Bauxite & 74 & 3.15 \\
\hline
\end{tabular}

The X-ray diffraction patterns reported a higher amount of cordierite phase for mix I than for mix II, as it is observed in Table 4. The mix I had a big amount of fine particles which contributed in an important way to the formation of the cordierite phase, however, it was utilized a bigger amount of water for its preparation and the physical properties for this mix were poor in comparison with those ones of the mix II. Other main phases detected in this analysis were mullite, cristobalite, alpha-alumina and magnesium oxide. It is necessary to remark that particulate size distribution is a very important factor in the quantity and type of phases formed for this ULCC.

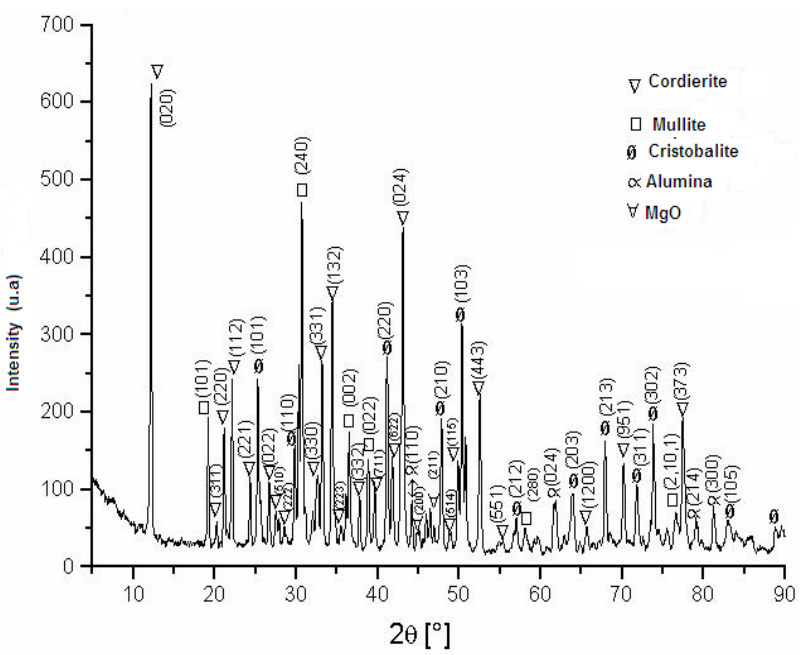

(a)

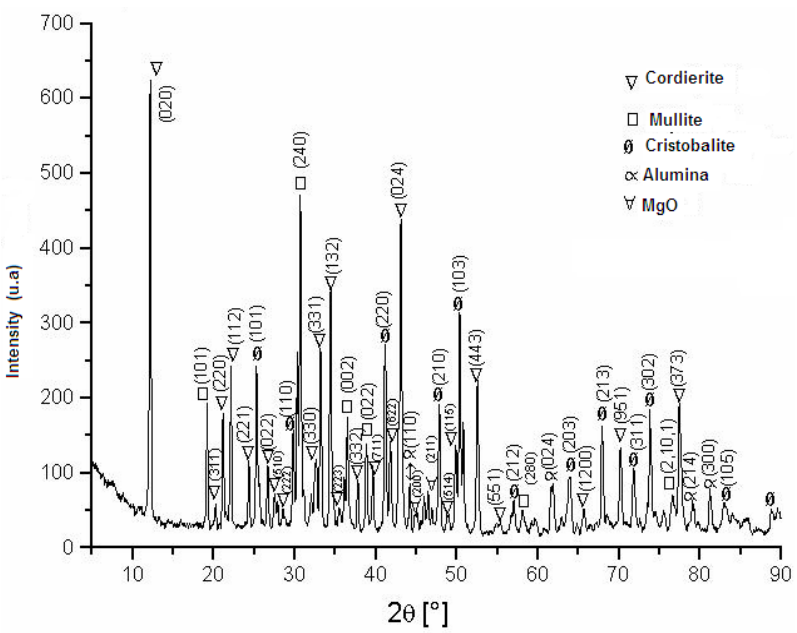

(b)

Figure 1. Patterns of X-ray Diffractions: (a) mix I, (b) mix II burned.

Table 4. Phase quantity in the mixtures.

\begin{tabular}{|c|c|c|c|c|c|}
\hline $\begin{array}{l}\text { MIX/ } \\
\text { Phase }\end{array}$ & $\begin{array}{c}\text { Cordierite } \\
\text { (\%) }\end{array}$ & $\begin{array}{c}\text { Mullite } \\
\text { (\%) }\end{array}$ & $\begin{array}{c}\text { Cristobalite } \\
\text { (\%) }\end{array}$ & 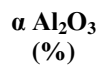 & $\begin{array}{c}\text { MgO } \\
(\%)\end{array}$ \\
\hline MIX I & 31.87 & 18.64 & 35.23 & 8.04 & 6.22 \\
\hline MIX II & 14.27 & 29.00 & 37.29 & 5.18 & 14.26 \\
\hline
\end{tabular}




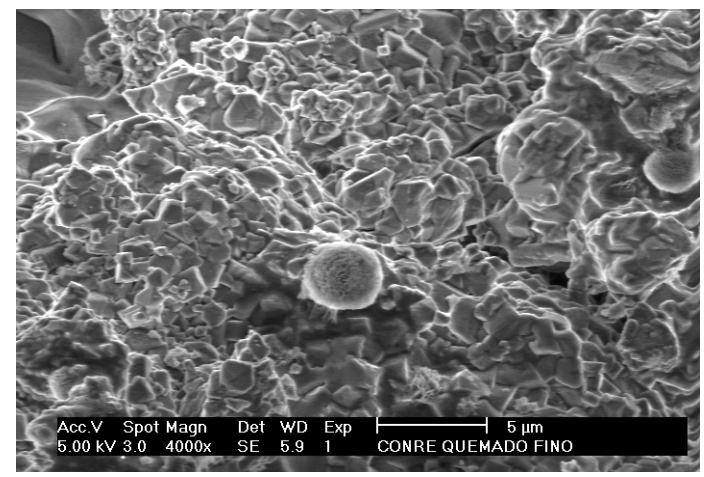

(a)

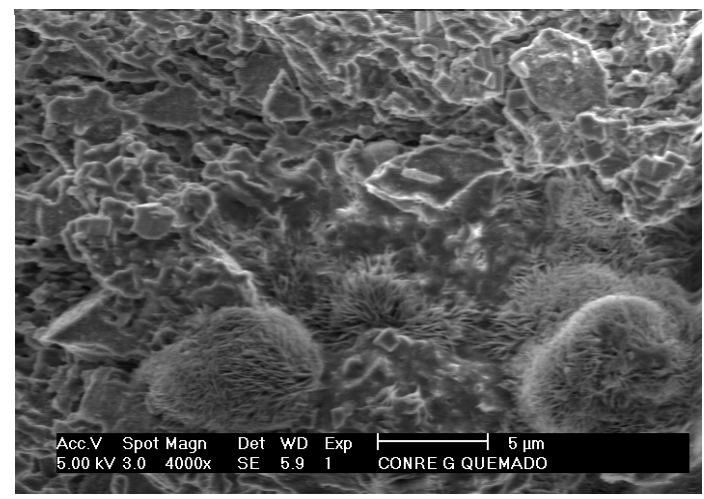

(b)

Figure 2. Micrographs: (a) mix I and (b) mix II.

\subsection{Scanning Electron Microscopy}

In the micrographs shown in Figure 2 we can observe material like flakes corresponding to cordierite, and liquid phases with composition of $\mathrm{Fe}_{2} \mathrm{O}_{3}, \mathrm{Na}_{2} \mathrm{O}, \mathrm{K}_{2} \mathrm{O}$ and $\mathrm{GeO}$ formed with the presence of $\mathrm{SiO}_{2}$ and detected by Micro analyses of SEM, all of these have low fusion points.

\section{Conclusions}

1. It was processed a refractory Cordierite ULCC mix, with level of cordierite phase commercially acceptable and with thixotropic properties.

2. The main physical properties of this type of ULCC are subjected to a very restricted particle sizes distribution to obtain the better physical properties after fired.

3. Further research work must be doing to improve in a better way the cordierite performance phase and also the final physical properties of the castable.

\section{REFERENCES}

[1] R.S. Lamar, M.F. Warner, Reaction and fired property studies of cordierite compositions J. Am. Ceram. Soc., 37, 12, pp. 602-610, 1954.

[2] L. A. Radzikhovskii, Cordierite bodies wity improved refractoriness. Keramika No. 6 p.p.21-22, June 1980.

[3] C.A. Bertran, N.T. da Silva, G.P. Thim Citric acid effect on aqueous sol-gel cordierite synthesis, J. Non-Cryst. Solids, 273, pp. 140-144, 2000.

[4] M. Awano, H. Takagi, Y. Kuwahara Grinding effects on the synthesis and sintering of cordierite J. Am. Ceram. Soc., 75, 9, pp. 2535-2540, 1992.

[5] Ö. Çakır, Production of cordierite from domestic raw materials, M.Sc. thesis, 1981. Middle East Technical University, Ankara.

[6] H. Sarpoolaky, K. Ahari, W. Lee, Ceram. Int., 28, , 487-493, 2002.

[7] E. A.Firoozjaei, A. Saidi, A.Monshi, P. Koshi, The effect of microsilica and refractory cement content on the properties of andalusite based Low cement castables used in aluminium casthouse, Ceramic 56, 411-421, 2010. 